\title{
DETERMINAN PEMILIHAN METODE KONTRASEPSI JANGKA PANJANG \\ OLEH WANITA USIA SUBUR DI DESA BEUSI \\ KABUPATEN MAJALENGKA TAHUN 2014
}

Oleh

\author{
Roschidah Putri Rizani; \\ roschidahputririzani@gmail.com
}

\begin{abstract}
A. Abstrak
Penelitian ini bertujuan untuk mengetahui faktor-faktor yang berhubungan dengan pemilihan Metode Kontrasepsi Jangka Panjang oleh wanita usia subur. Jenis penelitian adalah Kuantitatif dengan metode non eksperimen (observasional analitik). Hasil penelitian menunjukkan bahwa ada hubunngan yang signifikan antara umur, jumlah anak, pengetahuan, sikap, efek samping, status kesehatan dan biaya terhadap pemilihan MKJP oleh WUS di desa Beusi Kecamatan Ligung Kabupaten Majalengka 2014 dengan nilai $p$ value $<0,05$. Dan yang merupakan faktor dominan terhadap pemilihan MKJP adalah penghasilan.
\end{abstract}

Simpulan dari hasil penelitian diharapkan agar memilih metode kontrasepsi sesuai dengan kebutuhan dan dapat memanfaatkan program pemerintah terkait Keluarga Berencana bersubsidi bagi masyarakat yang berpenghasilan rendah, sehingga tetap dapat menggunakan MKJP sebagai upaya pencegahan resiko tinggi pada akseptor.

Kata Kunci : Pemilihan metode kontrasepsi jangka panjang, wanita usia subur 


\section{B. Latar Belakang}

Pada tahun 2010 di Indonesia, jumlah WUS sebanyak 4.918.271, dari jumlah ini dengan proporsi $11,72 \%$ (593.621 peserta) merupakan peserta KB baru dan 77,80\% (4.604.414 peserta) merupakan akseptor $\mathrm{KB}$ aktif. Menurut SDKI 2010-2012, prevalensi pemakaian kontrasepsi di Indonesia $60 \%$. Alat kontrasepsi yang banyak digunakan adalah metode suntik $(49,1 \%)$, pil $(23,3 \%)$, AKDR/ alat kontrasepsi dalam rahim (10,9\%), implant $(7,6 \%)$, metode operasi wanita/ MOW (6,5\%), kondom (1,6\%), dan metode operasi pria/MOP $(0,7 \%)$. Tahun 2011 peserta KB mencapai 5,6 juta, diikuti peningkatan pada tahun 2012 menjadi 6,5 juta akseptor. Pada tahun 2013 diperkirakan akseptor mampu mencapai angka 7 juta orang (SDKI, 2012).

Pelaksanaan program keluarga
berencana dinyatakan dengan
pemakaian alat/cara KB saat ini.
Pemakaian alat KB modern yang
dinyatakan dengan CPR modern di
antara WUS (15-49 tahun) merupakan
salah satu dari indikator universal akses
kesehatan reproduksi. Kelompook usia
reproduksi 25- 29 tahun adalah
penggunna KB terbanyak hampir $62 \%$.
Hasil Riskesdas 2013, pemakaian
cara/alat KB di Indonesia sebesar 59,7
persen dan CPR modern sebesar 59,3
persen.Diantara penggunaan KB
modern tersebut, sebagian besar
menggunakan cara KB suntikan
(34,3\%), dan merupakan penyumbang
terbesar pada kelompok non MKJP dan
jenis hormonal. Pelayanan KB di
Indonesia sebagian besar diberikan oleh
bidan (76,6\%) di fasilitas pelayanan
swasta yaitu tempat praktek bidan
(54,6\%) (Riskesdas, 2013).
Pelayanan kontrasepsi (PK)
adalah salah satu jenis pelayanan KB
yang tersedia.Sebagian besar akseptor
KB memilih dan membayar sendiri

berbagai macam metode kontrasepsi yang tersedia. Faktor-faktor yang dapat mempengaruhi akseptor dalam memilih metode kontrasepsi antara lain yaitu faktor wanita yang meliputi umur, gaya hidup, frekuensi senggama, jumlah keluarga yang diinginkan, pengalaman dengan metode kontrasepsi yang lalu, dan sikap kewanitaan dan kepriaan; Faktor kesehatan meliputi status kesehatan, riwayat haid, riwayat keluarga, pemeriksaan fisik, dan pemeriksaan panggul; faktor metode kontrasepsi meliputi efektivitas, efek samping, dan biaya (Hartanto, 2004).

Berdasarkan data BKKBN di atas, jenis kontrasepsi yang paling banyak digunakan adalah suntik padahal jenis kontrasepsi suntik bukanlah jenis kontrasepsi jangka panjang. Namun demikian, pemakaian kontrasepsi sebaiknya disesuaikan dengan kebutuhan PUS, seperti keinginan mengatur jumlah anak dan jarak serta usia ideal melahirkan sesuai dengan hak reproduksi untuk mewujudkan keluarga yang berkualitas.

\section{METODE}

Penelitian ini menggunakan jenis kuantitatif, dengan metode non eksperimen(observasional analitik)dimana survei atau penelitian yang mencoba menggali bagaimana dan mengapa fenomena itu terjadi, menggunakan desain Cross Sectional Study (potong lintang) ialah suatu penelitian untuk mempelajari dinamika korelasi antara faktor-faktor risiko dengan efek, dengan cara pendekatan, observasi atau pengumpulan data sekaligus pada suatu saat (point time approach) artinya tiap subjek penelitian hanya di observasi sekali saja dan pengukuran dilakukan terhadap status karakter atau variabel subjek penelitian diamati pada waktu yang sama 
Populasi dalam penelitian ini yaitu WUS yang menggunakan alat kontrasepsi di Desa Beusi, Kecamatan Ligung Kabupaten Majalengka. Sampel yang digunakan adalah WUS yang telah menikah dan menjadi akseptor KB yang datang ketempat pelayanan KB yang ada di Desa Beusi kecamatan Ligung kabupaten Majalengka sebanyak 236 orang. Tehnik pemilihan sampel dalam penelitian ini diambil secara random sampling dengan menggunakan Cluster Random Sampling. Pemilihan sampel dilakukan pada seluruh WUS yang terdiri dari satu kelompok (cluster). Setiap WUS didalam kelompok yang terpilih akan diambil sebagai sampel. Menentukan jumlah sampel menggunakan perhitungan sampel proporsional dengan distribusi sampel dari masing-masing kelompok (RW) sebagai berikut:

Tabel 4.2

Distribusi sampel

\begin{tabular}{|c|c|c|c|}
\hline No & RW & PUS & Sampel \\
\hline 1 & Sabtu & 125 & 27 \\
\hline 2 & Jumat & 197 & 41 \\
\hline 3 & Kamis & 153 & 33 \\
\hline 4 & Rebo & 243 & 52 \\
\hline 5 & Entuk & 392 & 83 \\
\hline \multicolumn{2}{|r|}{ Jumlah } & 1110 & 236 \\
\hline
\end{tabular}

Teknik pengumpulan data untuk mengetahui faktor-faktor yang berhubungan dengan pemilihan Metode Kontrasepsi Jangka Panjang oleh wanita usia subur menggunakan kuesioner yang dibuat sendiri oleh peneliti. Jenis data dalam penelitian ini menggunakan data primer yaitu data yang diperoleh langsung dari responden.

\section{HASIL PENELITIAN}

1. Karakteristik responden berdasarkan umur

Tabel 1

Distribusi Frekuensi WUS Berdasarkan Umur di Desa Beusi Kecamatan Ligung Kabupaten Majalengka Tahun 2014

\begin{tabular}{|l|c|c|}
\hline Usia & Frekuensi & $\begin{array}{c}\text { Persentase } \\
(\mathbf{\%})\end{array}$ \\
\hline $20-35$ tahun & 122 & 51,7 \\
\hline$>35$ tahun & 114 & 48,3 \\
\hline Total & $\mathbf{2 3 6}$ & $\mathbf{1 0 0 , 0}$ \\
\hline
\end{tabular}

Berdasarkan hasil penelitian pada tabel 1 disimpulkan bahwa WUS yang masuk katagori berumur20-35 tahunadalah 51,7\%, sedangkan WUS yang masuk katagori berumur> 35 tahun adalah $48,3 \%$. 
Karakteristik responden berdasarkan jumlah anak

Tabel 2

Distribusi Frekuensi WUS Berdasarkan Jumlah anak di Desa Beusi Kecamatan Ligung Kabupaten MajalengkaTahun 2014

\begin{tabular}{|l|l|l|}
\hline Jumlah Anak & $\begin{array}{l}\text { Frekuensi } \\
(\mathbf{n})\end{array}$ & $\begin{array}{l}\text { Persentase } \\
(\mathbf{\%})\end{array}$ \\
\hline$\leq 2$ anak & 70 & 29,7 \\
\hline$>2$ anak & 166 & 70,3 \\
\hline Total & $\mathbf{2 3 6}$ & $\mathbf{1 0 0 , 0}$ \\
\hline
\end{tabular}

Berdasarkan hasil penelitian pada table 2 diketahui bahwa WUS yang paritasnya $\leq 2$ anak adalah $29,7 \%$, dan WUS yang paritasnya $>2$ anak adalah $70,3 \%$.

Karakteristik responden berdasarkan penghasilan

Tabel 3

Distribusi Frekuensi WUS berdasarkan Penghasilan di Desa Beusi Kecamatan Ligung Kabupaten Majalengka Tahun 2014

\begin{tabular}{|l|l|l|}
\hline Penghasilan & $\begin{array}{l}\text { Frekuensi } \\
(\mathbf{n})\end{array}$ & $\begin{array}{l}\text { Persentase } \\
(\mathbf{\%})\end{array}$ \\
\hline$<$ Rp. 1.500.000; & 166 & 70,3 \\
\hline$\geq$ Rp. 1.500.000; & 70 & 29,7 \\
\hline Total & $\mathbf{2 3 6}$ & $\mathbf{1 0 0 , 0}$ \\
\hline
\end{tabular}

Berdasarkan tabel 3 penghasilan dapat disimpulkan bahwa WUS yang Penghasilan $<$ Rp.1.500.000,- adalah 70,3\%, sedangkan yang berpenghasilan $\geq$ Rp.1.500.000,adalah $29,7 \%$.

4. Hubungan antara faktor-faktor penghambat pelaksanaan konseling dengan tingkat keberhasilan pada pelayanan kebidanan

Tabel 4.6.

Tabel Silang Faktor-faktor Penghambat Pelaksanaan Konseling dengan Tingkat Keberhasilan pada Pelayanan Kebidanan di Puskesmas Wilayah Sleman

\begin{tabular}{|c|c|c|c|c|c|c|c|c|c|c|c|}
\hline \multirow{4}{*}{\multicolumn{2}{|c|}{$\begin{array}{l}\text { Faktor Penghamba } \\
\text { Pelaksanaan Konseling }\end{array}$}} & $\overline{\mathrm{Ti}}$ & gkat & & eberhas & & pada & \multirow{3}{*}{\multicolumn{2}{|c|}{ Total }} & \multirow{4}{*}{$X^{2}{ }_{h i t}$} & \multirow{4}{*}{$\begin{array}{l}P \\
\text { Value }\end{array}$} \\
\hline & & & yanan & \multirow{2}{*}{\multicolumn{2}{|c|}{$\begin{array}{l}\text { Kebidanan } \\
\text { Sedang }\end{array}$}} & & & & & & \\
\hline & & \multicolumn{2}{|c|}{ Rendah } & & & \multicolumn{2}{|c|}{ Tinggi } & & & & \\
\hline & & $\overline{\mathrm{F}}$ & $\%$ & $\bar{F}$ & $\%$ & $\bar{F}$ & $\%$ & $\mathrm{~N}$ & $\%$ & & \\
\hline \multirow{4}{*}{$\begin{array}{l}\text { Internal } \\
\text { dan } \\
\text { eksternal }\end{array}$} & Menghambat & 4 & 80 & 1 & 20 & 0 & 0,00 & 5 & 16,67 & & \\
\hline & $\begin{array}{l}\text { Tidak } \\
\text { menghambat }\end{array}$ & 1 & 5,88 & 14 & 82,35 & 2 & 11,76 & 17 & 56,67 & \multirow[t]{2}{*}{$25,3789,49$} & 0,000 \\
\hline & $\begin{array}{l}\text { Sangat tidak } \\
\text { menghambat }\end{array}$ & & 0,00 & 3 & 37,50 & 5 & 62,50 & 8 & 26,67 & & \\
\hline & Total & 5 & 16,67 & 18 & 60,00 & 7 & 23,33 & 30 & 100,0 & & \\
\hline
\end{tabular}

Sumber: (Data Primer diolah, 2010) 
Hasil analisa kategori responden, variabel faktor-faktor penghambat pelaksanaan konseling terdiri dari 3 kategori yaitu: menghambat, tidak menghambat dan sangat tidak menghambat, sedangkan variabel tingkat keberhasilan pada pelayanan kebidanan terdiri dari 3 kategori, yaitu rendah, sedang dan tinggi.

Dari 5 responden yang memiliki faktor-faktor penghambat pelaksanaan konseling menghambat, $80,00 \%$ mempunyai tingkat keberhasilan rendah pada pelayanan kebidanan, 20,00\% mempunyai tingkat keberhasilan sedang. Dari 18 Responden memiliki faktor penghambat pelaksanaan konseling yang tidak menghambat, 5,26\% mempunyai tingkat keberhasilan rendah pada pelayanan konseling, 82,35\% mempunyai tingkat keberhasilan sedang dan 11,76 mempunyai tingkat keberhasilan tinggi. Dari 7 responden memiliki faktor penghambat pelaksanaan konseling yang sangat tidak menghambat, 37,5\% mempunyai tingkat keberhasilan sedang pada pelayanan kebidanan dan 62,50\% mempunyai tingkat keberhasilan pelaksanaan tinggi.

Berdasarkan uji statistik dengan menggunakan alat analisis chi square, diperoleh nilai $\mathrm{X}^{2}$ hitung $=25,378$ dengan $p$ value adalah 0,000 . Derajat bebasnya sebesar $(\mathrm{m}-1)(\mathrm{n}-1)$. Jika angka dimasukkan dalam rumus tersebut maka diperoleh derajat bebasnya adalah (3-1)(3-1) $=4$. Nilai $X_{\text {tabel }}^{2}(\mathrm{df}=4$, taraf signifikan $\alpha=0,05)$ adalah 9,49. Hasil analisa data perbandingan antara nilai $X^{2}$ hitung dengan nilai $X^{2}$ tabel, dimana nilai $X^{2}$ hitung $(25,378)>X^{2}$ tabel $(9,49)$ dengan $p$ value $0,000<0,05$. Dari hasil tersebut, dapat disimpulkan bahwa terdapat hubungan yang bermakna/signifikan antara faktor-faktor penghambat pelaksanaan konseling dengan tingkat keberhasilan pada pelayanan kebidanan.

\section{E. PEMBAHASAN}

Pelayanan kebidanan merupakan bagian integral dari pelayanan kesehatan, yang diarahkan untuk mewujudkan

kesehatan keluarga dalam rangka tercapainya keluarga yang berkualitas. Pelayanan kebidanan merupakan layanan yang diberikan oleh bidan sesuai dengan kewenangan yang diberikannya dengan maksud meningkatkan kesehatan ibu dan anak dalam rangka tercapainya keluarga berkualitas, bahagia dan sejahtera (Rahyani, 2001). Sasaran pelayanan kebidanan adalah individu, keluarga dan masyarakat yang meliputi upaya peningkatan, pencegahan, penyembuhan dan pemulihan.

Dari jumlah persentase faktorfaktor penghambat pelaksanaan konseling sebagian besar tidak memiliki hambatan dalam memberikan konseling bahkan ada yang sangat tidak menghambat. Hal ini

kemungkinan dikarenakan faktor pengetahuan dan keterampilan tentang konseling, serta kemampuan bidan dalam membentuk jejaring yang baik karena bidan merupakan tenaga pelayanan kesehatan yang sudah terlatih dan profesional dalam memberi bimbingan, asuhan dan penyuluhan kepada ibu hamil, persalinan, nifas dan menolong persalinan dengan tanggungjawabnya sendiri serta memberikan asuhan pada bayi baru lahir dan bayi.

Tingkat keberhasilan suatu konseling yang di laksanakan dapat di tentukan dengan tercapainya tujuan dari konseling itu sendiri. Selain itu, dengan menerapkan langkah-langkah proses konseling yang sesuai juga sangat mempengaruhi keberhasilan dari suatu pelaksanaan konseling.

Suatu proses konseling tanpa
didasari oleh pengetahuan dan keterampilan yang baik tidak akan mudah untuk dilakukan. Pada praktiknya, selalu ditemui hambatan-hambatan yang datang baik dari bidan sendiri sebagai konselor ataupun dari luar. Menurut Wulandari (2009), dari pelaksanaan konseling di 
harapkan dapat menghasilkan suatu sikap kemandirian klien dalam hal peningkatan kemampuan klien dalam upaya mengenal masalah, merumuskan alternatif pemecahan masalah, dan menilai hasil secara cepat dan cermat; klien memiliki pengalaman dalam menghadapi masalah dan melaksanakan pemecahan masalah kesehatan; klien memiliki rasa percaya diri dalam menghadapi masalah kesehatan dikemudian hari; munculnya kemandirian dalam masalah kesehatan.

\section{F. SIMPULAN DAN SARAN}

Keberhasilan suatu konseling yang dilaksanakan dapat ditentukan dengan tercapainya tujuan dari konseling itu sendiri. Selain itu, menerapkan langkahlangkah proses konseling yang sesuai juga sangat mempengaruhi keberhasilan dari pelaksanaan konseling. Suatu proses konseling tanpa didasari oleh pengetahuan dan keterampilan yang baik tidak akan mudah untuk dilakukan.

\section{G. DAFTAR PUSTAKA}

Rahyani. 2001. Hambatan- Hambatan yang Dialami Bidan Dalam Melakukan Konseling Pada Klien Dalam Pelayanan Kebidanan di Puskesmas Kota Yogyakarta, Universitas Gajah Mada, Skripsi (Tidak Dipublikasikan)

Wulandari, D. 2009. Komunikasi dan Konseling Dalam Praktik Kebidanan. Nuha Medika. Yogyakarta.

Yulifah, R. 2009. Komunikasi dan Konseling Dalam Kebidanan. Salemba Medika. Jakarta. 